\title{
Demography and the Economy
}

\author{
Edited by John B. Shoven \\ Chicago: University of Chicago Press 2011 \\ ISBN 978-0226754727 \\ Hardcover, \$110.00, 431 pp.
}

\author{
Reviewed by Frank T. Denton, Professor Emeritus \\ Department of Economics, McMaster University (Hamilton ON) \\ dentonf@mcmaster.ca
}

This book is an edited collection of papers presented at a National Bureau of Economic Research conference held at Yountville, California, in April 2008. There are ten chapters, each followed by a discussion, plus a good ten-page introduction by the editor. There are twenty-nine contributors (authors and discussants), of whom twenty-five can be classified as economists, according to their affiliations, and four as demographers. The imbalance is perhaps misleading; demographic economics (population economics, economic demography) is a thriving field of economics, and is well represented by the demography-savvy economist contributors.

The book is certainly worth a look if you are interested in the overall subject. It is not likely a book you would want to read from cover to cover, though; as with just about any collection of conference papers, there is a diversity of topics and approaches to topics, and no single "story line," but one can pick and choose. Presumably it would be of greater interest generally to economists, but there are chapters that demographers might especially like too: "The future of American fertility" (Samuel Preston, Caroline Hartnett); "Fertility theories: Can they explain the negative fertility-income relationship?” (Larry Jones, Alice Schoonbroodt, Michèle Tertilt); "The final inequality: Variance in age at death" (Shripad Tuljapurkar); "Women's education and family behavior: Trends in marriage, divorce, and fertility" (Adam Isen, Betsey Stevenson). To be sure, economist readers may find these chapters interesting as well (especially the one by Jones et al.), and demographers may find some of the more economics-oriented ones interesting.

One oddity for a book with a title that seems to promise comprehensiveness is the following. Aside from the aging process itself (movement from one age group to the next), the drivers of population change are fertility, mortality, and migration. Fertility and mortality receive their due, but the book is silent on the subject of migration. There is no attention given to international or interregional movement of populations, its determinants and effects, and virtually no significant reference to it anywhere in the book; the index contains not a single entry for migration, immigration, or emigration. To a reviewer writing from a Canadian perspective, that does indeed seem odd, as forecasts of the Canadian population make it clear that demographic growth in the coming decades is almost certainly going to be dependent on immigration, and people in many other countries would no doubt have a similarly strong interest in the subject. It would appear that the editor had the issue on his mind, and perhaps was a bit defensive in the introduction: "The two biggest drivers of population growth and population age structure are fertility and mortality. In fact, from a global perspective, they are the only two drivers, since immigration has to net to zero." Yes, but the book is not concerned with global population change but rather with developments in particular countries.

The main focus of the book is the United States, but other countries do get some attention. (Canada gets only passing mention, in Chapter 8, "Aging populations, pension operations, potential economic disappointment, and its allocation", by Sylvester Schieber.) Chapter 5, "Old Europe ages: Reform and reform backlashes" (Axel Börsch-Supan, Alexander Ludwig), focuses mainly on continental Europe's three largest countries, France, Germany, and Italy ("the core of Old Europe," as the authors put it), with some comparisons to the US. The 
chapter provides demographic and macroeconomic forecasts to the middle of the century for the big three, based on some formal growth modelling. Chapter 10, the final chapter, "Italians are late: Does it matter?" (Francesco Billari, Guido Tabellini), considers the phenomenon of "late transition to adulthood" in Italy: "Young adults tend to study longer; enter the labor market later; leave the parental home, cohabit or marry, and become a parent later." Does it matter for the population and the economy? Yes, according to the authors, although there are caveats and a reluctance to "draw clear-cut policy implications." (The connection with Italy's very low fertility level is conspicuous, and there are also employment, productivity, and other connections.) There is some treatment of other countries here and there throughout the book (Swedish mortality patterns get a lot of attention by Tuljapurkar in Chapter 6), but for the book as a whole, the US is the main recipient of attention.

The policy implications of population aging are at the forefront of concern in much of the book: Chapter 4, "Adjusting government policies for age inflation" (John Shoven, Gopi Shah Goda); Chapter 7, "Demographic trends, housing equity, and the financial security of future retirees" (James Poterba, Steven Venti, David Wise); Chapter 8, "Aging populations, pension operations, potential economic disappointment, and its allocation" (Sylvester Schieber); and Chapter 9, "Financing Medicare: A general equilibrium analysis" (Orazio Attanasio, Sagiri Kitao, Giovanni Violante). The effects of population aging on pensions, healthcare costs, and the economy generally are (and will be for a very long time) major concerns in the US and many other countries, and the book reflects those concerns.

Summing up: A good collection of studies by a good collection of authors on topics at the interface of demography and economics. Too bad that migration did not get some attention, but overall I give the book a high grade and recommend it. 